\title{
SOSIALISASI PEMBERIAN BOLU KUKUS DAUN KATUK UNTUK MENINGKATKAN PRODUKSI ASI PADA IBU MENYUSUI DI PUSKESMAS PANTAI CERMIN KABUPATEN SERDANG BEDAGAI
}

\author{
Raini Panjaitan ${ }^{1 *}$, Reno Irwanto ${ }^{1}$, Nadia Husna ${ }^{1}$, Wira Maria Ginting ${ }^{1}$, Desri \\ Meriahta Girsang ${ }^{1}$, Andreais Boffil Cholilullah ${ }^{1}$ \\ ${ }^{1}$ Program Studi Gizi Institut Kesehatan Medistra Lubuk Pakam \\ Jl. Sudirman No. 38 Lubuk Pakam Kab. Deli Serdang, \\ Sumatera Utara - Indonesia \\ *email korespondensi author: raini0938p@gmail.com
}

DOI $10.35451 / j p k . v 1 i 1.705$

\begin{abstract}
Abstrak
Pemberian air susu ibu secara eksklusif merupakan pilihan terbaik untuk bayi yang baru lahir hingga usia 2 tahun. Masalah yang timbul pada ibu menyusui adalah produksi jumlah ASI yang tidak maksimal. Salah satu penyebab masalah tersebut adalah asupan gizi yang rendah sehingga banyak bayi yang kebutuhan gizinya kurang terpenuhi. Pelaksanaan sosialisasi pengabdian masyarakat ini telah dilakukan selama empat hari di Puskesmas Pantai Cermin. Tujuan kegiatan ini adalah untuk meningkatkan produksi ASI ibu menyusui melalui pemberian bolu kukus daun katuk. Ibu menyusui diberikan 1 porsi bolu kukus daun katuk yang terdiri dari 3 potong yang masing-masing beratnya 15 gram selama empat hari. Pada hari pertama tim pelaksana melakukan edukasi tentang ASI melalui ceramah dan diskusi serta memperkenalkan produk bolu kukus daun katuk dilanjutkan dengan demonstrasi pembuatan bolu kukus daun katuk dan pemberian bolu kukus daun katuk kepada peserta. Pemberian bolu kukus daun katuk dilanjutkan hingga hari ke empat dan lembar observasi tentang frekuensi menyusui dibagikan setiap hari. Berdasarkan sosialisasi ini didapatkan hasil bahwa ibu menyusui mengalami peningkatan frekuensi menyusui dalam 24 jam. Disimpulkan bahwa produk bolu kukus daun katuk efektif meningkatkan produksi ASI.
\end{abstract}

Kata kunci : Daun katuk, air susu ibu, ibu menyusui

\begin{abstract}
Exclusive breastfeeding was the best choice for newborns up to 2 years of age. The problem that arises in breastfeeding mothers was the production of the amount of milk that was not optimal. One of the causes of this problem was low nutritional intake so that many babies had less nutritional needs. This community service outreach has been carried out for four days at the Pantai Cermin Health Center. The purpose of this activity was to increase breastfeeding production of breastfeeding mothers through the provision of katuk leaf steamed sponge. Breastfeeding mothers are given 1 serving of katuk leaf steamed sponge, which consists of 3 pieces, each pieces was 15 grams for four days. On the first day, the implementation team conducted education about breast milk through lectures and discussions and introduced the katuk leaf steamed sponge product, followed by a demonstration of making katuk leaf steamed sponge and giving katuk leaf steamed sponge to the participants. The distribution of katuk leaf steamed sponge was continued until the fourth day and the observation sheet on the frequency of breastfeeding was distributed every day. Based on this socialization, it was found that breastfeeding mothers had an increasing of the
\end{abstract}


frequency of breastfeeding within 24 hours. It was concluded that the katuk leaf steamed sponge product was effective in increasing breast milk production.

Keywords: katuk leaves, breast milk, breastfeeding

\section{Pendahuluan}

Pertumbuhan dan perkembangan anak perlu diperhatikan sejak lahir. Pertumbuhan anak ditandai adanya perubahan ukuran badan atau yang berkaitan dengan perubahan ukuran, besar, jumlah atau dimensi tingkat sel hingga individu. Sedangkan perkembangan anak merupakan peningkatan kemampuan struktur dan fungsi tubuh yang lebih kompleks yang ditandai dengan kemampuan berbicara, berjalan, berlari dan lainnya. Kekurangan gizi pada bayi dapat mengakibatkan terhambatnya maupun terganggunya pertumbuhan dan perkembangan (Fitri dkk 2014). Bayi berusia 0-24 bulan masa dimana perkembangan dan pertumbuhan yang sangat pesat disebut periode emas (golden period) atau periode masa kritis. Pada periode ini dapat terwujud jika anak menerima asuhan dan asupan gizi yang sesuai secara optimal (Rahmad, 2017). Masalah atau gangguan yang timbul pada tumbuh kembang adalah tinggi badan pendek, gangguan berbicara, gangguan gerak kasar, gerak halus, sosialisasi dan kemandirian. Pemberian air susu ibu (ASI) merupakan pilihan yang optimal bagi bayi yang baru lahir dan diberikan secara eksklusif sejak usia 0-6 bulan. Menurut (WHO, 2011), bahwa sebaiknya bayi yang baru lahir diberi ASI secara eksklusif selama 6 bulan, kemudian dilanjutkan hingga anak berusia 2 tahun. Beberapa penelitian telah membuktikan bahwa bayi yang mengkonsumsi ASI mempengaruhi tumbuh kembang secara optimal.
Berdasarkan data (Riskesdas, 2018), bahwa pola pemberian ASI pada bayi umur 0-6 bulan di Indonesia sebanyak $37,3 \%$ dengan ASI eksklusif, 9,3\% dengan ASI parsial, dan 3,3\% ASI predominan yaitu menyusui bayi tetapi pernah memberikan sedikit air atau minuman berbasis air sebelum ASI keluar). Masalah yang timbul pada ibu menyusui ialah jumlah produksi ASI yang tidak maksimal. Salah satu penyebab masalah tersebut adalah asupan gizi ibu yang rendah sehingga banyak bayi yang kebutuhan gizinya kurang terpenuhi, hal ini dikarenakan ibu tidak dapat memberikan ASI maksimal yang sesuai dengan kebutuhan nutrisi bayi (Triananinsi dkk, 2020). Berdasarkan pandangan di atas perlu dilakukan upaya meningkatkan produksi ASI, dengan mengkonsumsi daun katuk, dalam bentuk produk bolu kukus. Berdasarkan penelitian Panjaitan dkk (2020) bahwa dengan pemberian bolu kukus daun katuk dapat meningkatkan frekuensi menyusui dengan rata-rata 10,40 kali dalam 24 jam dan dapat meningkatkan lama menyusui dengan rata-rata 9,74 setiap kali ibu menyusui bayi. Pelaksanaan pengabdian masyarkat ini bertujuan untuk meningkatkan produksi ASI ibu menyusui melalui pemberian bolu kukus daun katuk bagi ibu yang menyusui di Puskesmas Pantai Cermin.

\section{Metode}

Metode pelaksanaan program pengabdian masyarakat diawali dari pendatan jumlah pegawai yang sedang menyusui di Puskesmas Pantai Cermin. 
Kemudian dilakukan edukasi melalui ceramah dan diskusi tentang manfaat pemberian ASI dan jenis bahan pangan yang mampu meningkatkan produksi ASI. Dilakukan demonstrasi penyajian bolu kukus daun katuk secara langsung beserta leaflet tentang jumlah takaran bahan agar dapat dilakukan di rumah oleh mitra kerja. Ibu menyusui diberikan 1 porsi atau terdiri dari 3 potong bolu kukus daun katuk yang masing-masing bolu kukus 15 gram. Pada saat pelaksanaan kegiatan dilakukan diskusi dan tanya jawab.

\section{Hasil Dan Pembahasan}

Pelaksanaan sosialisasi pemberian bolu kukus daun katuk kepada ibu yang menyusui di Puskesmas Pantai Labu. Dilaksanakan pada tanggal 23-27 Maret 2021 bertempat di Puskesmas Pantai Labu, Jalan Mayjen H. T. Rizal Nurdin No. 68 Pantai Cermin Kanan, Pantai Cermin
Kabupaten Serdang Bedagai, dengan jumlah peserta sebanyak 35 orang ibu menyusui.

Kegiatan ini dilaksanakan selama empat hari. Pada hari pertama tim pelaksana melakukan edukasi tentang ASI melalui ceramah dan diskusi. Adapun materi yang disampaikan adalah pengertian ASI, ASI eksklusif, karakteristik ASI, komponen ASI, manfaat ASI, jenis-jenis bahan makanan pendukung produksi ASI dan pengenalan produk bolu kukus daun katuk. Selanjutnya dilakukan demonstrasi pembuatan bolu kukus daun katuk dan pemberian bolu kukus daun katuk kepada peserta. Pada hari kedua dan ketiga pemberian bolu kukus daun katuk dan setiap harinya dibagikan lembar observasi yang berisi frekuensi menyusui. Pada hari ke empat dilakukan pemberian bolu kukus dan penutupan.

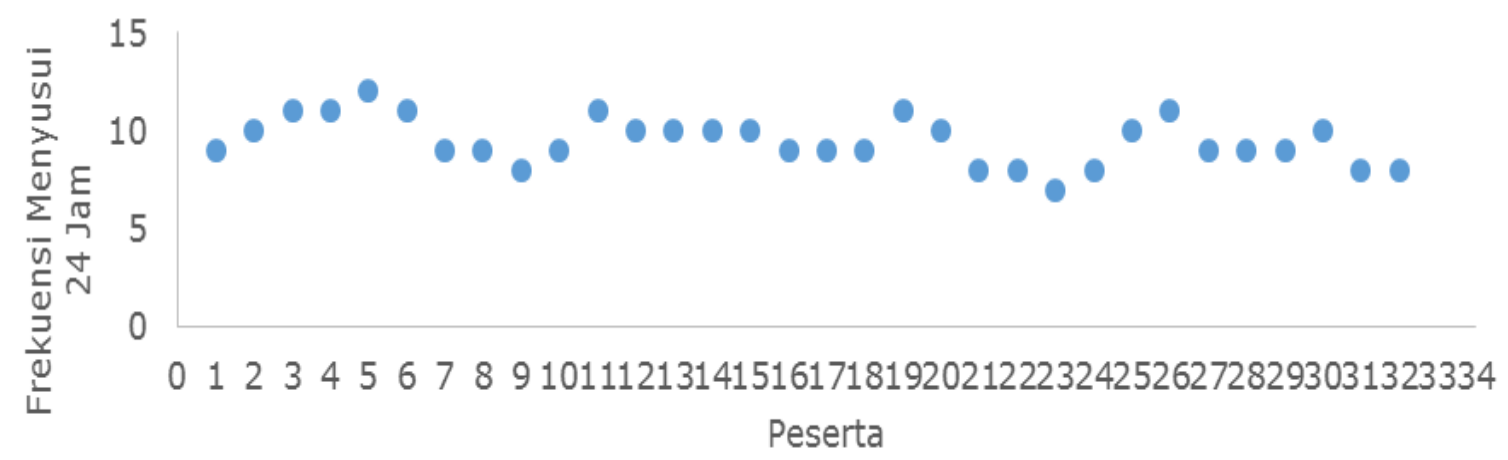

Gambar 1. Rata-Rata Frekuensi Menyusui Ibu Selama 4 Hari

Hasil observasi frekuensi ibu menyusui pada 34 ibu adalah rata-rata ibu mampu menyusui 9,46 kali dalam 24 jam. Berdasarkan observasi awal bahwa rata-rata ibu mampu memberikan ASI pada bayi sebanyak 7-8 kali setiap harinya. Pada sosialisasi ini menunjukkan bahwa pemberian bolu kukus daun katuk mampu meningkatkan frekuensi menyusui bagi ibu. Hal ini sesuai dengan penelitian yang telah dilakukan.

Berdasarkan hasil kegiatan
pengabdian ini, bahwa pihak
Puskesmas, kader kesehatan dan ibu-
ibu peserta memberikan respon yang
baik. hal ini dibuktikan dengan bahwa
seluruh peserta dapat mengikuti
kegiatan sosialisasi baik dari awal
kegiatan hingga akhir kegiatan. Ibu-
ibu peserta sangat antusias selama
mengikuti pelatihan karena banyak
mayoritas ibu menyusui yang berada di
lingkungan Puskesmas masih ibu


muda dan belum pernah menerima sosialisali tentang manfaat air susu ibu (ASI) dan jenis pangan yang mampu meningkatkan produksi ASI.

$$
\text { Adanya sosialisasi sebagai }
$$

upaya pengabdian kepada masyarakat para peserta dapat meningkatkan kemampuan dan pengetahuan cara meningkatkan produksi ASI. Salah satu langkah yang dapat dilakukan adalah pengembangan produk berbasis daun katuk dan tidak menutup kemungkinan para ibu menggunakan tanaman yang endemik di daerah tersebut.

ASI dapat diproduksi dan dikeluarkan dipengaruhi dua hormon yaitu hormon prolaktin dan oksitosin (Mutiara dkk, 2012). Berdasarkan beberapa penelitian dapat diketahui bahwa daun katuk mengandung senyawa galactagogue. Senyawa ini dipercayai mampu memicu produksi ASI. Disamping itu juga menghasilkan senyawa steroid dan polifenol yang dapat meningkatkan kadar hormon prolaktin (Juliastuti, 2019). Hasil penelitian Rahmanisa dan Aulianova (2016) bahwa senyawa alkaloid dan sterol yang terkandung di dalam daun katuk efektif meningkatkan produksi ASI.

\section{Kesimpulan}

Pelaksanan kegiatan sosialisasi pemberian bolu kukus daun katuk ini telah berjalan dengan baik dan sesuai dengan yang diharapkan, baik tim pelaksana, mitra dan para peserta. Setelah mendapatkan sosialisasi para peserta mendapat informasi dan pengetahuan tentang manfaat ASI dan pembuatan produk berbasis daun katuk untuk peningkatan produksi ASI. Dari hasil sosialisasi selama empat hari bahwa ibu menyusui mengalami peningkatan frekuensi menyusui selama 24 jam atau per harinya.

\section{Ucapan Terima Kasih}

Penulis mengucapkan terima kasih kepada Puskesmas Pantai Cermin Kabupaten Serdang Bedagai, yang telah membantu penulis dalam kegiatan sosialisasi bagi ibu menyusui, serta tim Prodi Gizi, terima kasih atas segala kerjasamanya.

\section{Daftar Pustaka}

Fitri, I., D. Chundrayetti, E., \& Semiarty, R. (2014). Hubungan Pemberian Asi Dengan Tumbuh Kembang Bayi Umur 6 Bulan Di Puskesmas Nanggalo. Jurnal FK UNAND, 3(2), 137-140.

Juliastuti. (2019). Efektivitas Daun Katuk (Sauropus Androgynus) Terhadap Kecukupan Asi Pada Ibu Menyusui Di Puskesmas Kuto Baro Aceh Besar. Indonesia Journal For Health Sciences, 3(1), 1-5.

Mutiara, Erli, Adikahriani, \& Siti., W. (2012). Pengembangan Formula Biskuit Daun Katuk Untuk Meningkatkan Produksi ASI. Penelitian Kesehatan. Universitas Negeri Medan.

Panjaitan., R. Irwanto., R. Husna., H. \& Cholilullah., B., A. (2020). Pengaruh Pemberian Bolu Kukus Daun Katuk Terhadap Produksi Asi Di Wilayah Kerja Rumah Sakit Grandmed Lubuk Pakam. JURNAL KESMAS \& GIZI (JKG), 3(1), 110114.

Rahmanisa, S., \& Aulianova, T. (2016). Efektifivitas Ekstraksi Alkaloid Sterol Daun Katuk (Sauropus Androgynus) Terhadap Produksi Asi. Medical Journal Of Lampung University, 5(1), 117121.

Rahmad, A., H., A. (2017). Pemberian Asi Dan Mp-Asi Terhadap Pertumbuhan Bayi Usia 6-24 Bulan. Jurnal Kedokteran Syiah Kuala, 17(1), 8-14.

Riset Kesehatan Dasar (Riskesdas). (2018). Laporan Nasional 2018. Jakarta: Badan Penelitian dan Pengembangan Kesehatan Depkes RI. 
Received: 31 May 2021 :: Accepted: 23 June 2021 :: Published: 30 June 2021

Triananinsi, N., Andryani, Y, Z, Basri, $F$,. (2020). HUBUNGAN PEMBERIAN SAYUR Daun Katuk Terhadap Kelancaran Asi Pada Ibu Multipara Di Puskesmas Caile. Jurnal of Healthcare Technology And Medicine, 6(1), $12-20$

World Health Organization (WHO). (2011). Exclusive breastfeeding for six Months best for babies everywhere.

https://www.who.int/mediacenter/ news/statements/2011/breastfeed ing 20110115/en/ 